\title{
ANTHROPOGENIC IMPACT ON PLANKTON AND BENTHOS ASSEMBLAGE IN THE LAGOS LAGOON, NIGERIA
}

\author{
Adiaha Alda Alex Ugwumba1, Imeh Kokoete Esenowo*2 \\ ${ }^{1}$ University of Ibadan, Faculty of Science, Department of Zoology, Ibadan, Nigeria \\ ${ }^{2}$ University of Uyo, Faculty of Sciences, Department of Animal and Environmental Biology, Akwa Ibom State, \\ Nigeria
}

*Corresponding Author, Email: adiaha4me@yahoo.co.nz

\section{ARTICLE INFO}

Received: 20 July 2019

Accepted: 23 September 2020

\section{ABSTRACT}

The physico-chemical parameters, plankton and macro-benthic invertebrates of the Lagos Lagoon (Badore, Ajah), Lagos State, Nigeria were studied between February and July 2018 at four sampling stations in a disparate range of human activities and impact. The result of phytoplankton analysis indicated a total of 56 genera with 40 genera within Bacillariophyta, accounting for $72 \%$ of the abundance. Zooplankton comprised 26 genera with $82 \%$ of the abundance of crustacea. The benthic macroinvertebrates were composed of mollusca, arthropoda and annelida. Results also indicated that the main drivers affecting the abundance and distribution of planktonic and benthic invertebrates were water temperature, $\mathrm{pH}$, TDS and EC. The monthly variations of physicochemical parameters in the Lagoon could be the result of human activities associated with transportation, fishing and domestic sewage disposal from the surrounding settlements. Therefore, it is necessary that relevant authorities keep in check some of these activities around the Lagoon as well as educate the population on the necessity for the conservation of these water resources.

\section{Keywords:}

Physico-chemical parameters

Phytoplankton

Zooplankton

Macroinvertebrates

Sewage water

How to Cite
Ugwumba, A. A. A., Esenowo, I. K. (2020): Anthropogenic impact on plankton and benthos assemblage in the Lagos Lagoon, Nigeria. Croatian Journal of Fisheries, 78, 173-182. DOI: 10.2478/cjf-2020-0017.

\section{INTRODUCTION}

Anthropogenic activities such as sand mining within and around the Lagos Lagoon is characterized by the increased nutrient load with its consequence on the indigenous flora and fauna (Nwankwo, 1996; Phillips et al., 2012). The productivity of any water body is determined by the amount of plankton it contains as they are the major primary and secondary producers of the aquatic environment (Azrina et al., 2005). Plankton organisms occur in open waters and move primarily with general water motions (Ovie et al., 2009). The plankton and benthos species composition could be used to evaluate the ecological status of aquatic habitats because of their quick response to environmental changes (Onyema et al., 2007). These organisms are very good indicators of water qualities due to possessing a narrow range of tolerance to environmental perturbations. 
While some are very vulnerable and sensitive to pollution, others can survive and reproduce in disturbed and extremely polluted waters (Popoola and Otalekor, 2011). The distribution of benthos fauna is determined by numerous factors such as the physical nature of the substratum, depth, nutritive content, degree of stability and oxygen content of the water body (George et al., 2009). Benthic organisms are threatened by changes in their habitat which are associated with pollution, erosion and siltation (Lydeard et al., 2004). The Badore in Ajah axis of the Lagos Lagoon is located in the eastern part of the Lagos Lagoon; it is relatively undisturbed by human activities compared to the western part of the lagoon (Nkwoji and Igbo, 2010). There have been several studies on the ecological state of the western part of the Lagos Lagoon (Ajegunle, Ijora, Apapa, Ikorodu, Iddo) due to the mining of sand activities. The work of Ajao and Fagade (1990) reported species that are characteristic of stressed environments such as polychaetes Capitella capitata (Fabricius, 1780), Nereis pelagica (Linnaeus, 1758) and Polydora cornuta (Bosc, 1802) in the western part of the Lagoon. Ajao and Fagade (2002) also reported declines in the abundance and distribution of benthic fauna, and through the food webs negative effects on fish caused by pollution effects from anthropogenic inputs. The aim of this study was to assess the water quality of the Lagos Lagoon at Badore Ajah to ascertain the impact of anthropogenic activities on the plankton and benthos communities, thereby providing valuable information towards the sustainable management of these water resources.

\section{MATERIALS AND METHODS}

\section{Study area}

Badore is situated in the eastern side of the Lagos Lagoon of Lagos State with an estimated area of $257.49 \mathrm{~km}^{2}$ (Fig 1). The Lagoon is characterized by a humid tropical climate with an annual average Relative Humidity of $80 \%$ and atmospheric temperature ranges between $26^{\circ} \mathrm{C}$ and $29^{\circ} \mathrm{C}$ (Olaniyan, 1975). The water depth increases sharply towards the mid-channel zone to a range of $15 \mathrm{~m}$ and $25 \mathrm{~m}$, probably due to the sand mining activities in the area. The annual rainfall is $4021 \mathrm{~mm}$ with a peak in July and August; least rainfall occurs between December and February (Hastenrath, 1985). The Lagos Lagoon represents an extremely important ecosystem for Nigeria, with a wide range of ecosystem services such as artisanal fisheries and a major means of transportation to other parts of Lagos City (Esenowo and Ugwumba, 2010). It is densely covered with littoral mangrove assemblages characterized by floating higher plants such as duckweed (Lemna spp.), water lettuce (Pistia spp.) and water hyacinth (Echiorna crassepes). Human activities associated with the area are transportation, fishing and domestic sewage disposal from the surrounding settlements.

Sample collection was carried out monthly between February and July of 2018. Four sampling stations were selected based on human activities in the areas and accessibility (Fig. 1), and the positions of the sampling stations were accurately located by using Geographical Positioning System (GPS) kit (IEC -529 IPX7 Model): station 1 , close to the shore with fishing boats and human

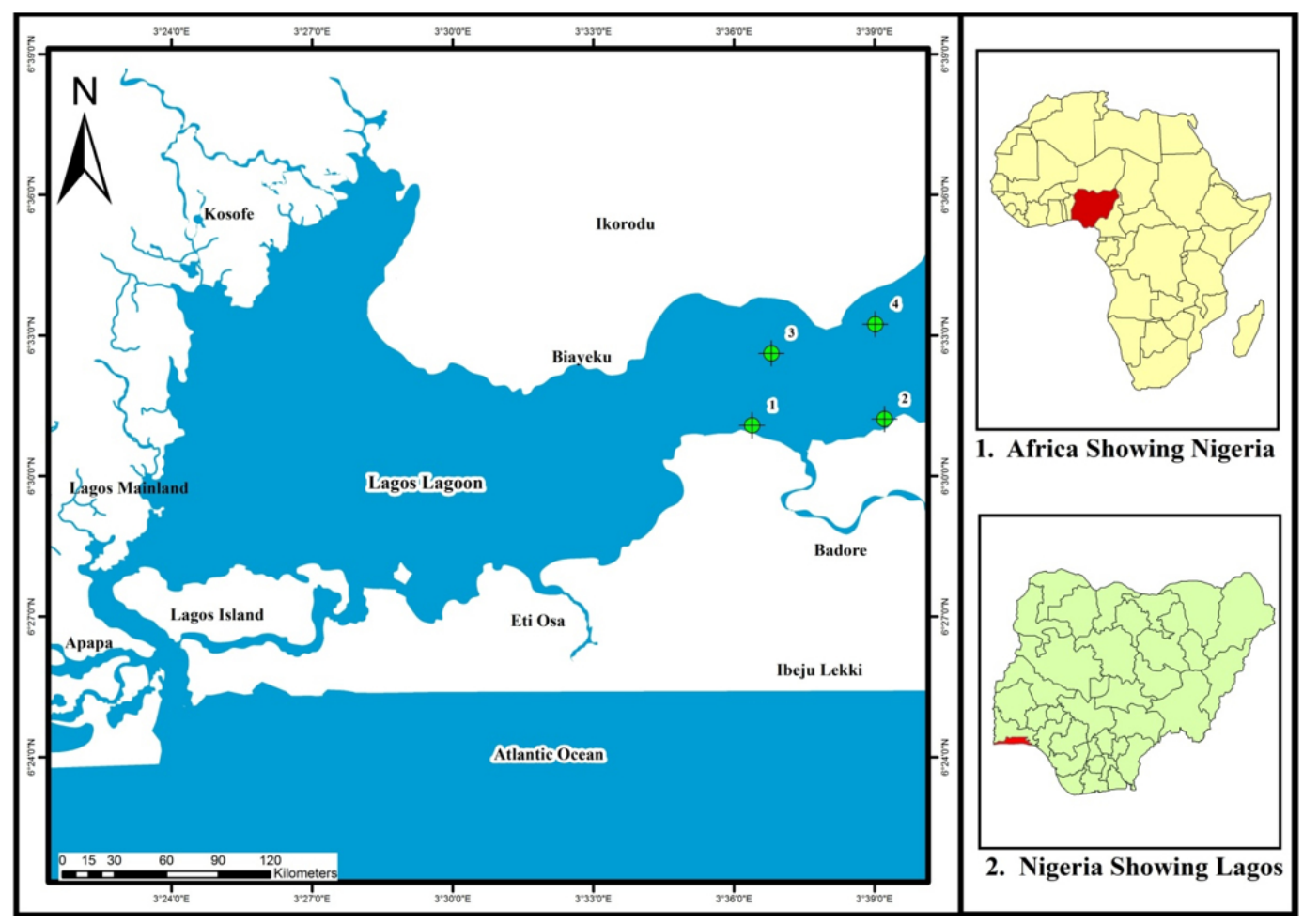

Fig 1. Map of the Lagos Lagoon showing study area with sampling stations (1-4)

Source: Cartographic Studio, University of Uyo 
settlements on the shoreline $\left(6^{\circ} 31^{\prime} 04.60^{\prime \prime} \mathrm{N} 30^{\circ} 36^{\prime} 23.23^{\prime \prime}\right.$ E); station 2, next to the shore and laden with littoral mangroves $\left(6^{\circ} 31^{\prime} 04.60^{\prime \prime} \mathrm{N} 3^{\circ} 39^{\prime} 12.94^{\prime \prime} \mathrm{E}\right)$; station 3, open waters, away from the shore $\left(6^{\circ} 32^{\prime} 36.97^{\prime \prime} \mathrm{N} 3^{\circ} 36^{\prime} 47.70^{\prime \prime}\right.$ E); station 4, relativity offshore, close to an electric power station and a shipwreck (6 $\left.6^{\circ} 33^{\prime} 14.36^{\prime \prime} \mathrm{N} 3^{\circ} 39^{\prime} 01.06^{\prime \prime} \mathrm{E}\right)$.

\section{Determination of physico-chemical parameters of the water}

Some physico-chemical parameters were measured in situ using a multi-parameter instrument (Horiba U-10) at all sampling sites: salinity, temperature, $\mathrm{pH}$, electrical conductivity (EC) and total dissolved solids (TDS), while others were measured in a laboratory using standard methods according to APHA (2005), using water samples collected in $250 \mathrm{~mL}$ bottles for dissolved oxygen (DO), biological oxygen demand (BOD), nitrate and phosphate. Sediment samples for heavy metals were collected using a hand corer ( $\varnothing 10 \mathrm{~cm} \times 100 \mathrm{~cm}$ length). Collected samples were prepared and analyzed according to the method of the Ministry of Environment, Japan (2004).

\section{Collection and analysis of plankton samples}

Plankton samples were collected with a plankton net (55 $\mu \mathrm{m}$ mesh size). Samples were collected into $250 \mathrm{~mL}$ bottles and immediately fixed and preserved in formalin (4\% solution) during the fieldwork and taken to the laboratory for identification and analysis. Species identification and classification were conducted under a microscope (ZEISS Microscope Primo Star, Magnification 100x), using keys by Hendey $(1958,1964)$, Needham and Needham (1962), Wimpenny (1966), Newell and Newell (1966), Patrick and Reimer (1975), Whitford and Schumacher (1973), Olaniyan (1969), Jeje and Fernando (1986, 1991), and Lange-Bertalot (1979).

\section{Collection and analysis of benthic macroinvertebrates}

Sediment samples were collected monthly using a van Veen grab with a sampling area of $225 \mathrm{~cm}^{2}$. Each sediment sample was diluted with water and sieved throughout a $0.5 \mathrm{~mm}$ mesh size. The residual samples retained on the sieve were placed on a white tray for sorting. The sorted benthic macroinvertebrates were preserved in $4 \%$ formalin in small glass jars. The identification of benthic macroinvertebrates was conducted under a stereomicroscope in the laboratory, using guides by Edmunds (1978) and Pennak (1978). Various organisms encountered were classified into specific levels as far as possible and the numbers of individuals were recorded.

\section{Statistical analysis}

Data on the benthic macroinvertebrates, plankton and physico-chemical parameters of water and sediments were subjected to descriptive statistics using IBM-SPSS 20.0 for Windows (SPSS Inc., USA). ANOVA was used to assess monthly variations in the physico-chemical parameters within and between the stations. Pearson's correlation coefficient was used to determine the relationship between physico-chemical parameters, plankton and benthos abundance.

\section{RESULTS}

\section{Temporal and spatial variation of environmental variables}

The detailed data obtained on variation in physicochemical factors and concentration of heavy metals were presented in Table 1 . The results from ANOVA did not indicate a significant difference of analysed parameters, spatially and temporary $(p>0.05)$. All the physico-chemical parameters intercorrelated positively and significantly ( $p$ $<0.05$ ) (Table 2).

Water temperature ranged around $30^{\circ} \mathrm{C}$, with highest values in July and the lowest in May, at sampling stations 1-3. At station 4, the highest temperatures were noticed in February, and slightly decreased towards July. The values of dissolved oxygen slightly increased between February and July, and averaged around $6 \mathrm{mg} \mathrm{O}_{2} \mathrm{~L}^{-1}$. Transparency was relatively constant in all sampled stations between February and May (around $200 \mathrm{~cm}$ ) and dropped steeply in June and July (around $75 \mathrm{~cm}$ ). pH was around 7.5 throughout the study period, except in March dropped to 5.5 .

Electrical conductivity showed the opposite trend than $\mathrm{pH}$, with lower constant values between February and May (around $0.05 \mathrm{mS}$ ) but then increased fivefold in June and July. During the sampling period, salinity oscillated at all stations from 32 to 33 ppt, except a slight drop in May to $30 \mathrm{ppt}$. Total dissolved solids increased, with minor oscillations between February and July (Table 1). Nitrate concentrations in comparison to other months (around $0.65 \mathrm{mg} \mathrm{N} \mathrm{L}^{-1}$ ) dropped at all four sampling stations between April and June ( 0.16 to $0.11 \mathrm{mg} \mathrm{N} \mathrm{L}^{-1}$ ). Phosphate concentrations were highest in April (around $0.5 \mathrm{mg} \mathrm{P} \mathrm{L}^{-1}$ ) and for the rest of the study period were mostly around $0.15 \mathrm{mg} \mathrm{P} \mathrm{L}^{-1}$. Biological oxygen demand at all sampling stations was $1.13 \mathrm{mgO}_{2} \mathrm{~L}^{-1}$ and increased to $3 \mathrm{mgO}_{2} \mathrm{~L}^{-1}$ in April and May.

Concentrations of mercury and arsenic averaged $0.11 \pm 0.00 \mathrm{mg} \mathrm{L}^{-1}$ and of cadmium $0.01 \pm 0.00 \mathrm{mg} \mathrm{L}^{-1}$ with very low oscillations, spatially and temporary, respectively. Concentrations of cadmium were slightly increased at station 4 in comparison to other sampling stations.

\section{Phytoplankton and zooplankton composition}

The percentage composition of phytoplankton identified in Badore-Ajah axis of the Lagos Lagoon during the study period is shown in Fig. 2. The phytoplankton comprised 56 genera out of which $\mathbf{4 0}$ genera were within Bacillariophyta (diatoms), eight genera Chlorophyta (green algae), six Cyanophyta (blue-green algae) and two genera were Euglenophyta (euglenoids). Also, diatoms accounted for $72 \%$ in abundance. 
A total of 26 genera belonging to Rotifera and Crustacea were encountered (Fig. 3). Rotifera had the highest representation with 19 genera, followed by Crustacea with 7 genera. The order Copepoda was the most abundant with $66 \%$, while Cladocera contributed with $16 \%$ in plankton. The phylum Rotifera had a total of $17 \%$ with Lecane lunaris (Ehrenberg, 1832) domination of 8\%, while Trichocerca capucina (Sudzuki, 1964) contributed with $3 \%$ in abundance. Phytoplankton and zooplankton abundance showed a negative correlation with most of the physico-chemical parameters $(p<0.05)$ (Table 2$)$.

Table 1. Spatial variation of the physico-chemical parameters in the Lagos Lagoon

\begin{tabular}{|c|c|c|c|c|c|}
\hline \multirow{2}{*}{ Water Quality Parameters } & \multicolumn{4}{|c|}{ Sampling Stations (Min-Max Values) } & \multirow{2}{*}{ Mean $\pm S D$} \\
\hline & 1 & 2 & 3 & 4 & \\
\hline Water temperature $\left({ }^{\circ} \mathrm{C}\right)$ & $29.20-30.30$ & $29.10-30.50$ & $29.50-30.10$ & $29.20-30.00$ & $29.88 \pm 0.16$ \\
\hline $\mathrm{DO}\left(\mathrm{mg} \mathrm{O}_{2} \mathrm{~L}^{-1}\right)$ & $4.90-7.14$ & $5.00-7.60$ & $4.50-7.20$ & $4.50-7.50$ & $6.08 \pm 0.03$ \\
\hline Transparency $(\mathrm{cm})$ & $85-196$ & $83-190.00$ & $65-187$ & $70-186$ & $151.5 \pm 3.66$ \\
\hline $\mathrm{pH}$ & $7.03-8.31$ & $5.51-8.28$ & $3.97-8.37$ & $4.95-8.30$ & $7.47 \pm 0.19$ \\
\hline $\mathrm{EC}(\mathrm{mS})$ & $0.4-0.27$ & $0.4-0.29$ & $0.4-0.27$ & $0.4-0.27$ & $0.12 \pm 0.10$ \\
\hline Salinity (\%o) & $29.60-33.30$ & $30.10-33.30$ & $29.50-33.00$ & $30.30-33.30$ & $32.21 \pm 1.31$ \\
\hline TDS (mg/L) & $2460-5223$ & $2730-5342$ & $2590-4434$ & $2532-4556$ & $3474 \pm 805$ \\
\hline Nitrate (mg N L-1) & $0.15-0.84$ & $0.11-0.95$ & $0.00-0.56$ & $0.00-0.54$ & $0.40 \pm 0.15$ \\
\hline Phosphate (mg P L-1) & $0.03-0.52$ & $0.02-0.58$ & $0.01-0.48$ & $0.03-0.48$ & $0.20 \pm 0.16$ \\
\hline $\mathrm{BOD}_{5} \mathrm{mgO}_{2} \mathrm{~L}^{-1}$ & $0.02-3.00$ & $.05-3.00$ & $0.03-3.00$ & $.03-3.00$ & $1.13 \pm 0.04$ \\
\hline Mercury (mg L-1) & $0.11-0.13$ & $0.11-0.12$ & $0.11-0.12$ & $0.11-0.12$ & $0.11 \pm 0.00$ \\
\hline Cadmium (mg L-1) & $0.01-0.02$ & 0.01 & 0.01 & $0.01-0.02$ & $0.01 \pm 0.00$ \\
\hline Arsenic $\left(\mathrm{mg} \mathrm{L}^{-1}\right)$ & $0.10-0.12$ & $0.10-0.12$ & $0.11-0.12$ & $0.11-0.12$ & $0.11 \pm 0.00$ \\
\hline
\end{tabular}

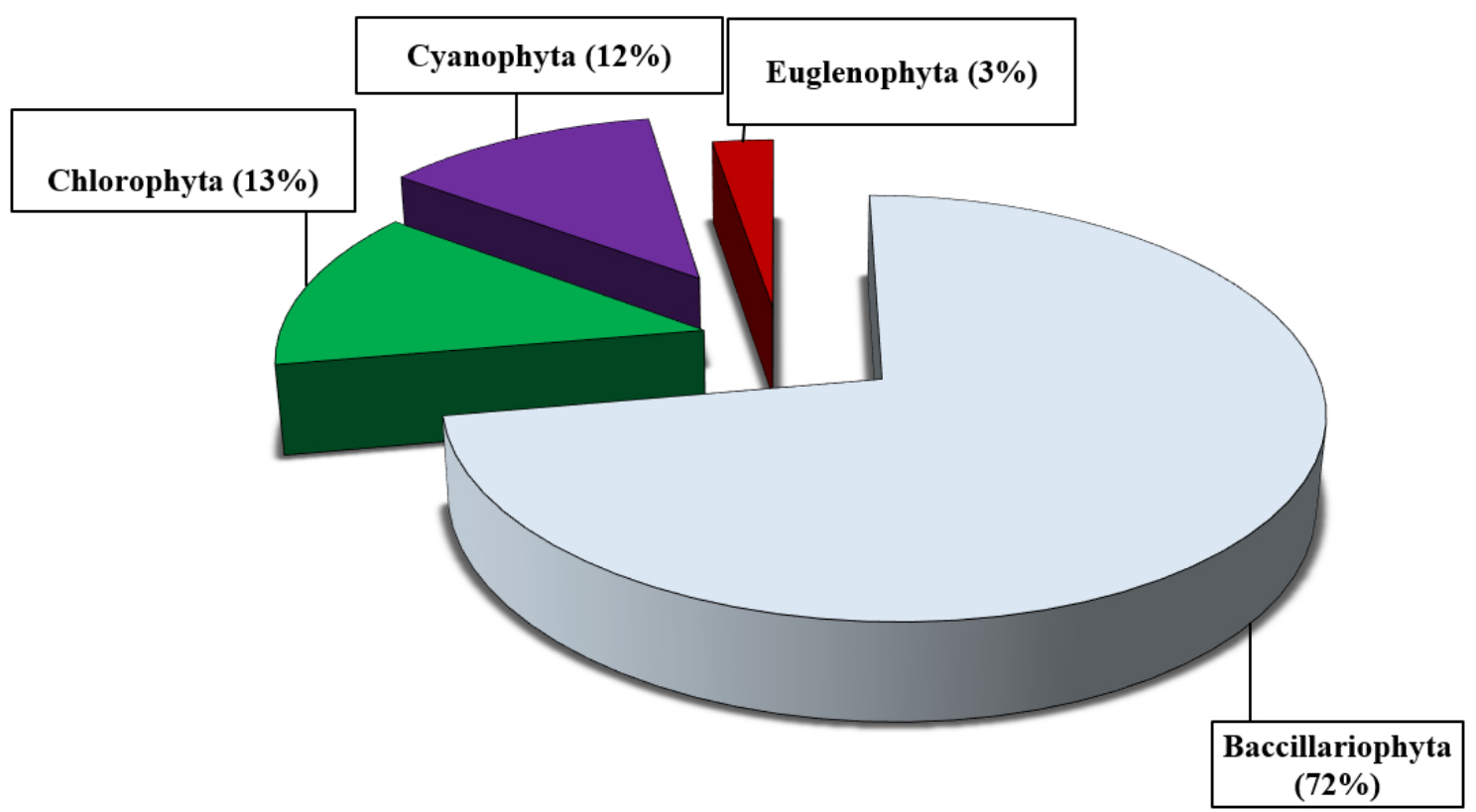

Fig 2. Composition of phytoplankton groups in Badore Ajah axis of the Lagos Lagoon 


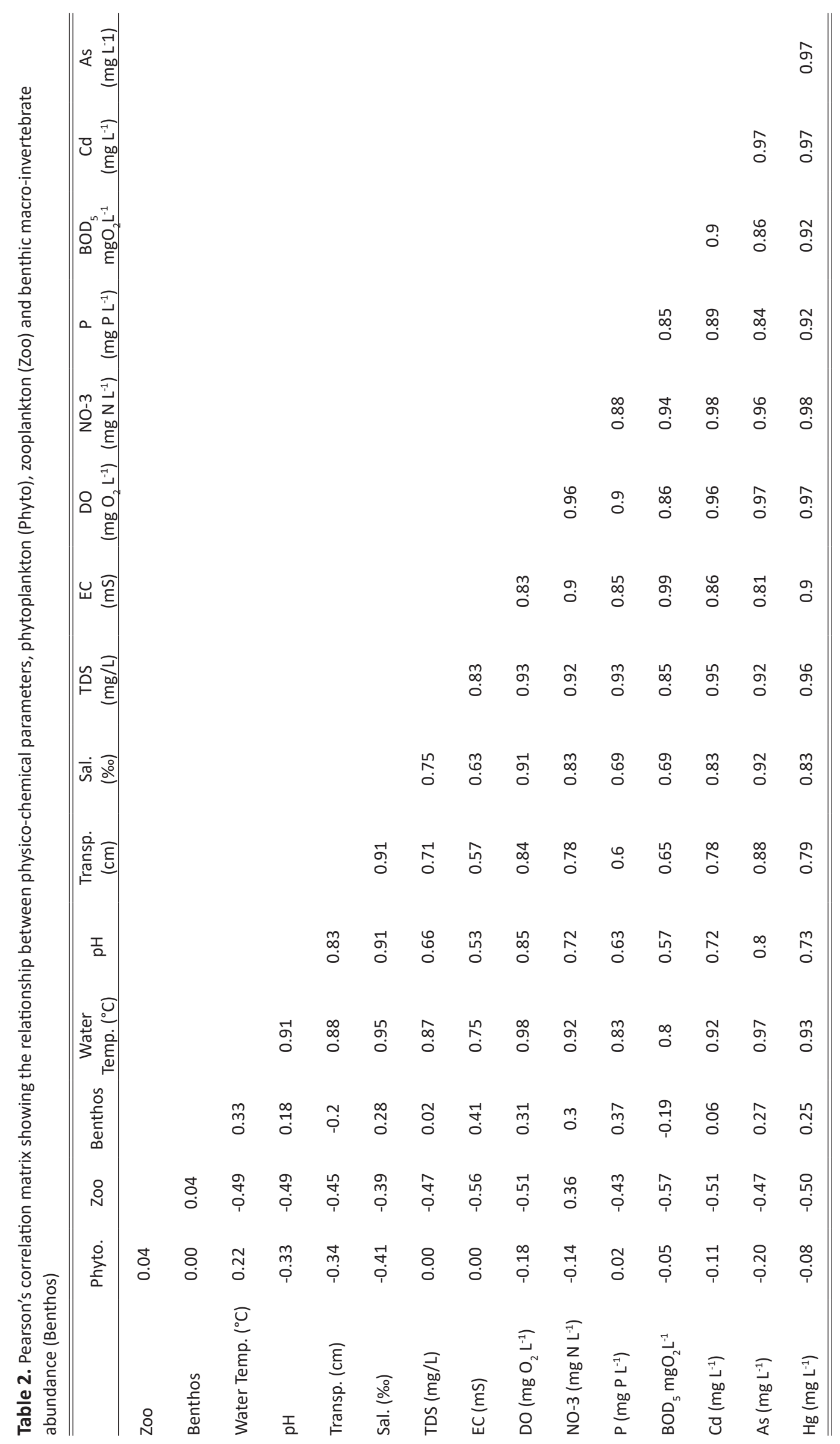




\section{Arachnida (7\%)}

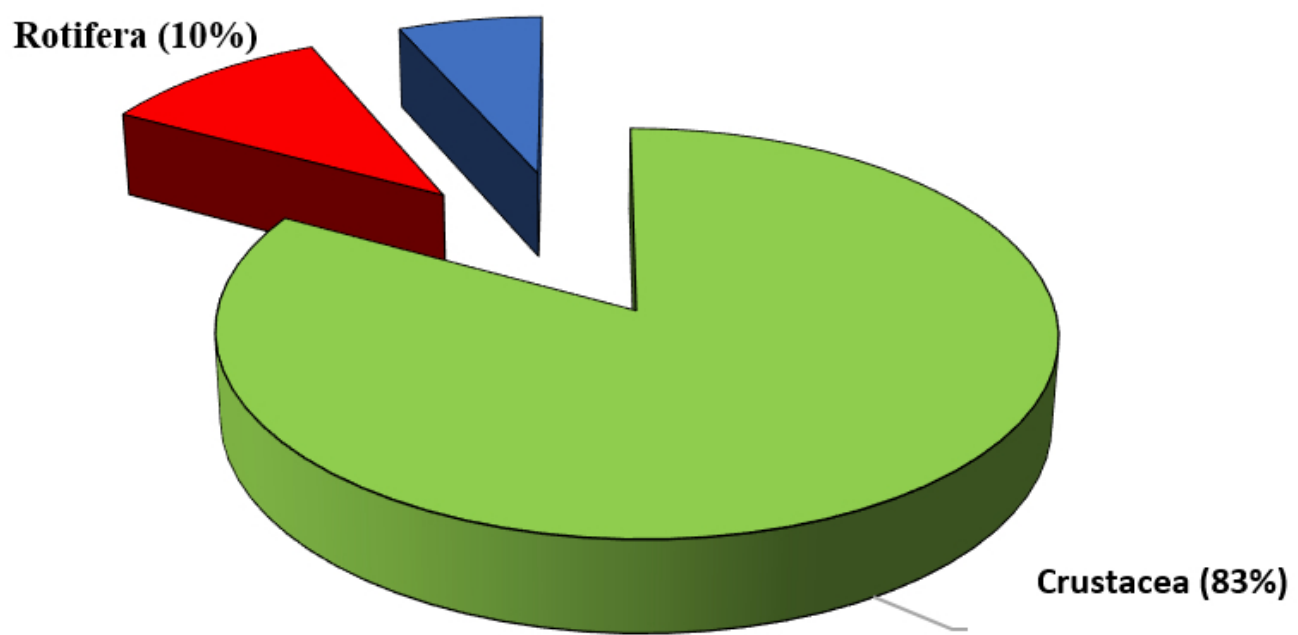

Fig 3. Composition of zooplankton groups in Badore Ajah axis of the Lagos Lagoon

\section{Benthic macro-invertebrate composition and abundance}

Nine taxa belonged to three phyla, Mollusca, Annelida and Arthropoda (Fig 4). Among Mollusca, class Gastropoda was represented by three families (Potamidae, Melanidae and Nieritidae) and class Bivalvia was represented by one family. Melanidae was represented by two species, Pachymelamia aurita (Muller, 1774) and P. fuscatus (Linnaeus, 1758), which had the highest percentage abundance of benthic macroinvertebrates encountered in the study, $49 \%$ and $25 \%$, respectively. The juvenile stages of four gastropod species were recorded: Tympanotonus fuscatus (Linnaeus, 1758), P. aurita (Muller, 1774), P.

fusca, (Linnaeus, 1758) and Aloidies trigona (Linnaeus, 1755). The phylum Arthropoda was represented by the classes Crustacea (Sesarmidae, Portunidae) and Insecta (caddisflies, Phryganeidae). The class Polychaeta in the phylum Annelida accounted for two families (Nereididae and Capitellidae); Nereididae was represented by one species (Nereis pelagica Linnaeus, 1758) with the lowest abundance among benthos (0.39\%). The benthic macroinvertebrates showed positive correlation with the physico-chemical parameters, except for $\mathrm{BOD}_{5} \mathrm{mgL}^{-1}$ which was negatively correlated $(p<0.05)$ (Table 2).

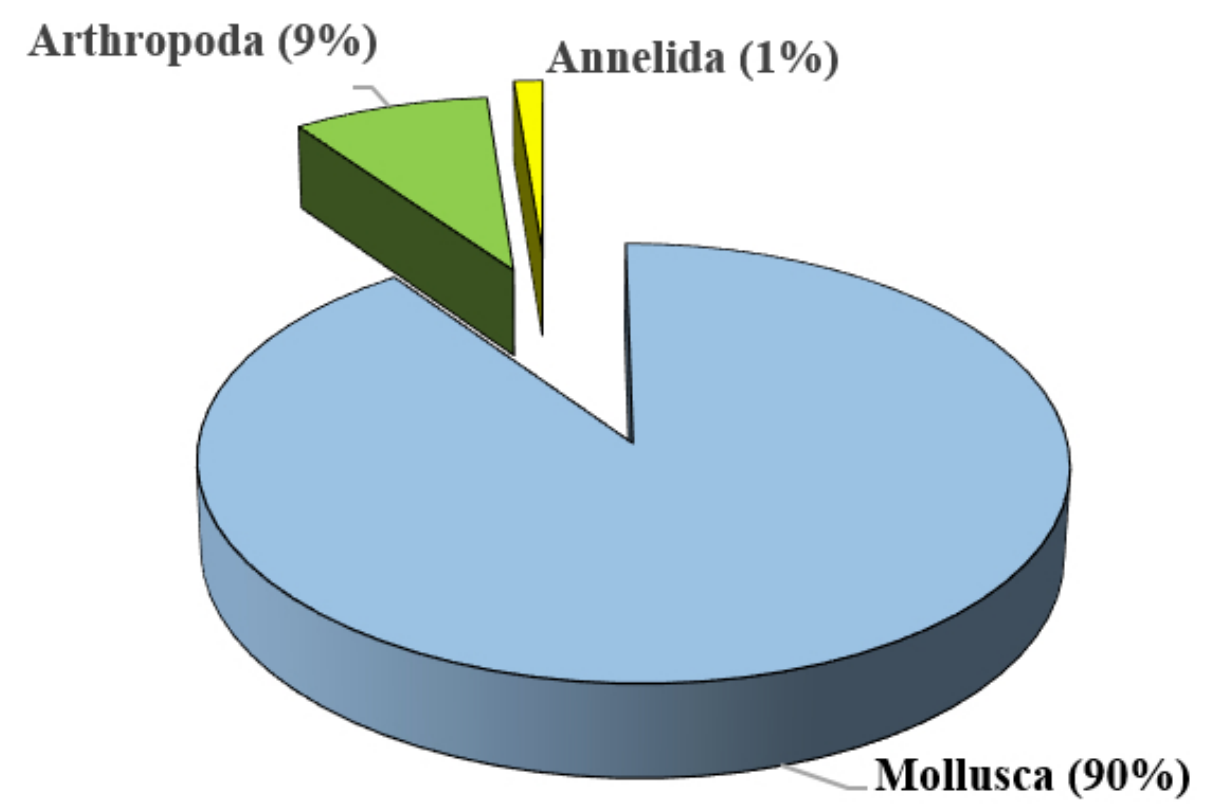

Fig 4. Composition of benthic macro-invertebrate groups in Badore Ajah axis of the Lagos Lagoon 


\section{DISCUSSION}

\section{Physico-chemical parameters}

Surface water temperature was high throughout the study period, whilst DO values were low and the ranges in the present study were within National Environmental Standards and Regulation Enforcement Agency (NESREA) acceptable limits (>5.0 mg/L) for aquatic life. These results were in accordance with reports by Poopola et al. (2015) and Fabunmi et al. (2015) that coastal waters require a minimum of $4.0 \mathrm{mg} / \mathrm{L}$, while aquatic prefer $5.0 \mathrm{mg} / \mathrm{L}$ of DO. Low transparency observed during the study could be a result of particulate suspended matter from the sand mining activities. Similar report by Clarke (2005) recorded lower transparency in the Ologe Lagoon in Lagos State and attributed it to human activities such as sand dredging on the lagoon. The $\mathrm{pH}$ range recorded in the present study is above 7 but lower than 8.5 which is optimal for biological productivity (Abowei, 2010). Electrical conductivity level in this study was low and this may be due to dilution by rainwater. Similar reports of low electrical conductivity by Omogoriola et al. (2012) of 0.05-0.08 mS was recorded on the western part of the Lagos Lagoon.

The Western part of the Lagos Lagoon has been reported to have a wide range of salinity differences as reported by Edokpayi and Nkwoji (2007), and Popoola et al. (2015). In the present study, salinity value ranges from 31.57 to $32.6 \%$ and this can be attributed to its proximity to the Atlantic Ocean, as also reported by Benson et al. (2015). Besides, the relatively constant salinity values recorded throughout the study may be due to tides of the study area, supported by even mixing of the water mass (Fabunmi et al., 2015).

Observed TDS of the study area was relatively high and this agreed with reports by Nwankwo et al. (2014) of 39$125.46 \mathrm{mg} / \mathrm{L}$ in the western part of the Lagos Lagoon. Elevated levels of TDS could be attributed to influx from nearby creeks and streams, household and industrial wastes.

The nutrients, nitrates and phosphates were relatively low compared to reports by Emmanuel and Onyema et al. (2007) of 3.05-6.82 mg/L, and Ladipo et al. (2011) of $6.4-7.9 \mathrm{mg} / \mathrm{L}$. According to Ediagbonya et al. (2015), unpolluted water generally contains nitrate below $1 \mathrm{mg} / \mathrm{L}$, hence the low values of this nutrient in the present study, while the heavy metals in sediments had values that were all within NESREA limits as acceptable for aquatic life. In the present study, $\mathrm{BOD}_{5} \mathrm{mgO}_{2} \mathrm{~L}^{-1}$ value was relatively low as compared to previous reports by Eurola et al. (2011) and Ladipo et al. (2011) with values of $6.0 \mathrm{mg} / \mathrm{L}$ and 58.0 $\mathrm{mg} / \mathrm{L}$, respectively. Alagoa and Aleleye-Wokoma (2012) reported that $\mathrm{BOD}_{5} \mathrm{mgL}^{-1}$ values of $4-7 \mathrm{mg} / \mathrm{L}$ represented slightly polluted water and more than $8 \mathrm{mg} / \mathrm{L}$ represented severely polluted water, while the value for the present study is below the range for these two groups.

Physico-chemical parameters such as DO, BOD, pH, nutrients and heavy metals were within limits set by the NESREA for aquatic life and the United States Environmental Protection Agency (USEPA), except for TDS that was high due to anthropogenic activities in the study area such as sand mining, and this could affect the productivity of the study area.

The phytoplankton population was dominated by diatoms, especially the pennate forms. This is attributed to the facts that they are the most obvious representative of the phytoplankton in sea, river and lakes. According to Nwankwo et al. (2014), the algae of the genus Aulacoseira granuta (Ehrenberg Simonsen, 1979) is a conspicuous taxon in the eastern zone of the Lagos Lagoon and this was less evident in the present study. Other observed genera of pennate diatoms were Biddulphia aurila (Edward, 1860), B. laevis (Edward, 1860), Gyrosigina balticum (Ehrenberg, 1853), Melosira moniliformis (C. Agardh, 1824), which are reported in brackish waters while blue-green algae Microcystis aeruginosa (Kutzing,1846) and M. flos-aquae (Kirchner, 1898) have been associated with cyanobacteria blooms (Nwankwo et al., 2014). It is generally thought that in brackish and marine habitats, rotifers play a minor role in community dynamics (Wen et al., 1999). The dominance of zooplankton by the species of class Crustacea (Cladocera and Copepoda) is attributed to the influence of salinity on the composition and organization of the zooplankton in the coastal water bodies. This was evident in all four studied stations and coincided with previous reports in the coastal and brackish waters in south-western Nigeria such as Onyema, (2013), Lawal-Are et al. (2010) and Yakub et al. (2012). Also, Emmanuel and Onyema (2007) reported that cladocerans and cyclopoid copepods were the dominant forms in fresh/low brackish waters, and the calanoid copepods were dominant forms in higher brackish waters. The dominance of these two groups of zooplankton was also confirmed in the present study.

The dominant organisms in brackish water benthic communities of the present study were gastropods, as also reported by Uwadiae (2009) and Nkwoji et al. (2010). The high occurrence and abundance of the genus Pachymelania, which contributed the most in the total populations, was reaffirmed by Omogoriola et al. (2012) and Nwankwo et al. (2014). Both papers confirmed the adaptation of the genus Pachymelania to freshwater and that they also preferred brackish waters of higher salinity. The presence of Aloidies trigona (Linnaeus, 1755) as one of the most occurring bivalves highlights the species abilities to adapt to the area of less organic matter associated with the eastern section of the Lagos Lagoon (Edokpayi and Nkwoji, 2007). The reduced occurrences of the polychaete worms Nereis pelagica (Linnaeus, 1758) and Capitella capitata (Fabricius, 1780) were in agreement with the previous studies of Edokpayi and Nkwoji (2007), Nkwoji and Igbo (2010), and confirmed that the eastern section of the Lagos Lagoon is less environmentally stressed. However, these polychaete species have been previously described as pollution indicators by Ogunwenmo and 
Kusemiju (2004). At the stations 2 and 4, the relatively low number of individuals were recorded, which could be attributed to the effects of intense human activities such as sand mining, known to destroy invertebrate habitats (Hoang et al., 2018). Dredging and sediment deposition has been reported to have a profound impact on the benthic community in the Lagos Lagoon. According to Appleby and Scarratt (1989), habitat alteration is the most significant cause of mortality in invertebrates.

Phytoplankton abundance and diversity indices reveal the presence of pollution indicator species of blue-green algae Oscillatoria tenius (C. Agardh ex Gomot, 1892) and Microcystis flos-aquae (Kirchner, 1898), as well as green algae Spirogyra spp. (Link1820) and S. Africana (Czurda, 1932) which indicate that the study area is prone to pollution.

The abundance of copepods and cladocerans indicates that the overall ecological status of the study area is moderate. However, the presence of benthic macroinvertebrate species as a biological indicator of water pollution such as N. pelagica (Linnaeus, 1758) and C. capitata (Fabricius, 1780) further reveal that the increased level of humaninduced activities may result in pollution. Therefore, it is necessary to ensure management measures to restore and maintain its resources for sustainable use.

\section{SAŽETAK}

\section{ANTROPOGENI UTJECAJ NA SASTAV PLANKTO- NA I BENTOSA U LAGOS LAGUNI, NIGERIJA}

Proučavani su fizikalno-kemijski parametri vode, plankton i makrobentoski beskralješnjaci u laguni Lagos (Badore, Ajah), država Lagos, Nigerija u razdoblju od veljače do srpnja 2018. na četiri lokacije za uzorkovanje u različitom rasponu ljudskih aktivnosti i utjecaja. Rezultat analize fitoplanktona ukazao je na ukupno 56 rodova s 40 rodova unutar Bacillariophyta. Zooplankton je obuhvaćao je 26 rodova s $82 \%$ zastupljenosti nižih rakova. Bentoski makroinvertebrati bili su sastavljeni od mekušaca, člankonožaca i kolutičavaca. Rezultati su također ukazali da su glavni pokretači koji utječu na brojnost i rasprostranjenost planktonskih i bentoskih beskralješnjaka temperatura vode, $\mathrm{pH}$, TDS i EC. Mjesečne promjene fizikalno-kemijskih parametara u laguni mogle bi biti rezultat ljudskih aktivnosti povezanih s prijevozom, ribolovom i ispuštanjem kanalizacije iz okolnih naselja. Smatra se da je neophodno da nadležne vlasti kontroliraju neke od navedenih aktivnosti oko lagune, kao i da stanovništvo educiraju o potrebi očuvanja ovih vodnih resursa.

Ključne riječi: Fizikalno-kemijski parametri, fitoplankton, zooplankton, makroinvertebrati, kanalizacijske vode

\section{REFERENCES}

Abowei, J. F. N. (2010): Salinity, dissolved oxygen, pH and surface water temperature conditions in Nkoro River, Niger Delta, Nigeria. Advance Journal of Food Science and Technology 2, 1, 36-40.

Ajao, E. A., Fagade, S.O. (1990): The distribution and abundance of Pachymelenia aurita in Lagos Lagoon, Nigeria. Archives fur Hydrbiologie 119, 475-488.

Ajao, E. A., Fagade, S.O. (2002): The benthic Macroinfauna of Lagos Lagoon. The Zoologist 1, 2, 1-15

Alagoa, K. J., Aleleye-Wokoma, I. P. (2012): Human Induced Variations of Selected Physicochemical Parameters of Taylor Creek in the Niger Delta, Bayelsa State, Nigeria. Resources and Environment 2, 2, 45-50.

APHA (2005): Standard methods for the examination of water and waste water, $21^{\text {st }}$ edition American Public Health Association, Washington, D. C. 1195 pp.

Appleby, J. A., Scarratt, D. J. (1989): Physical effects of suspended solids on marine estuarine fish and shellfish, with special reference to ocean dumping: A literature review. Canadian Technical Report of Fisheries and Aquatic Sciences No 1681. 2pp.

Azrina, M. Z., Yap, C. K., Rahim, I. A., Ismail, A., Tan, S. G. (2005): Anthropogenic Impacts on the distribution and biodiversity of benthic macroinvertebrates and water quality of the Langat River, Peninsular Malaysia, Ecotoxicology and Environmental Safety, 16, 184-210.

Benson, N. U., Adedapo, A. E., Eritobor, A. L., Udosen, E. D. (2015): Total dissolved inorganic carbon and physicochemical characteristics of surface microlayer and upper mixed layer water from Lagos Lagoon, Nigeria. Global NEST Journal 17, 2, 334-343.

Clarke O. E. (2005): The dynamics of Plankton population in Ologe Lagoon, Lagos, Nigeria. Ph.D. Thesis Dept. of Zoology, Lagos State University, 343 pp

Edmunds, J. (1978): Sea shells and other molluscs found on West African coast and estuaries. Ghana Universities Press, 87-146.

Ediagbonya, T. F., Nmema, E., Nwachukwu, P. C., Teniola, O. D. (2015): Identification and quantification of heavy metals, coliforms and anions in water bodies using enrichment factors. Journal of Environmental and Analytical Chemistry, 2, 146.

Edokpayi, C. A., Nkwoji, J. A. (2007): Annual changes in the physico-chemical and macrobenthic invertebrate characteristics of the Lagos Lagoon sewage dump site at Iddo, Southern Nigeria. Ecology, Environment and Conservation, 13, 1, 13-18.

Emmanuel, B. E., Onyema, I. C. (2007): The plankton and fishes of a tropical reek in South- Western Nigeria. Turkish Journal of Fisheries and Aquatic Sciences, 7, 105-113.

Eruola, A. O., Ufoegbune, G. C., Ojekunle, Z. O., Makinde, A. A., Ogunyemi, I. O. (2011): Analytical investigation of pollutants in Lagos coastal waters, Nigeria. Advances in Analytical Chemistry, 1, 8-11. 
Esenowo I. K., Ugwumba A. A. A. (2010): Composition and Abundance of Macrobenthos in Maidun River Ikorodu Lagos State, Nigeria. Research Journal of Biological Science 5, 8, 556-560

Fabunmi, I., Falilu A., Uyimadu, J. P., Popoola, S., Oyatola, O., Nwoko, C. (2015): On the physico-chemistry and nutrient profile in the Lagos harbour. Journal of Scientific Research and Reports, 8, 4, 1-13.

George, A.D.I., Abowei, J. F. N., E. R. Daka, (2009): Benthic macroinvertebrate fauna and physico-chemical parameters in Okpoka Creek sediments, Niger Delta, Nigeria. Int. J. Anim. Vet. Adv., 1, 59-65.

Hastenrath, S. (1985): Climate and Circulation of the Tropics. D. Reidel. Pub. Co. Dordrecht, Holland. 253 pp

Hendy, N. I. (1958): Marine diatoms from some West African ports. Journal of Royal Microscopic Society, 61, 23-25.

Hendey, N .l. (1964). An introductory account of the smaller algae of British coastal waters. Part 5, Bacillariophyceae (diatoms) Ministry of Agriculture, Fisheries Investigation series, 4, 314-317.

Hoang, H., Duong, T. T., Nguyen, K., Le, T. P., Luu, T. N. M., Duc, T., Le A., Ho, C., Dang, K., Nemery, J., Orange, D., Klein, J. (2018): Impact of anthropogenic activities on on water quality and plankton communities in the day river, Red river delta, Vietnam. Environmental monitoring and Assessment 190.10.1007/s/066-0176435-z.

Jeje, C.Y., Fernando, C. H. (1986): A practical guide to the identification of Nigerian Zooplankton (Cladocera, Copepoda and Rotifera). Published by KLRI, New Bussa, $142 \mathrm{pp}$.

Jeje, C. Y., Fernando, C. H. (1991): An illustrated guide to identification of Nigerian fresh water rotifers, Nigeria. Journal of Science, 25, 77-95.

Ladipo, M. K., Ajibola, V. O., Oniye S. J. (2011): Seasonal variations in physicochemical properties of water in some selected locations of the Lagos Lagoon. Science World Journal, 6, 4, 5-11.

Lange-Bertalot, H. (1979): Simonsenia, a new genus with morphology intermediate between Nitzschia and Surirella. Bacillaria, 2, 127-136

Lawal-Are, A. O., Onyema, I. C., Akande, T. R. (2010): The water chemistry, crustacean zooplankton and some associated faunal species of a tropical tidal creek in Lagos, Nigeria. Journal of American Science, 6, 1, 8190.

Lydeard, C., Cowie, R. H., Ponder, W. F., Bogan, A. E., Bouchet, P. (2004): The global decline of non-marine mollusks. Bioscience, 54, 321-330

Ministry of Environment, Japan. (2004). Mercury analysis manual. Retrieved on Nov 5, 2017 from https://ww.env. go.jp/press/pdf. 39 pp.

Needham, J. G., Needham, P. R. (1962): A guide of the study of freshwater biology, Holden Day Inc. San Francisco. 180pp.

Newell, G. E., Newell, R. C. (1966): Marine plankton: A practical guide. Revised edition. London: Hutchinson. 139-187pp.

Nkwoji, J. A., Igbo, J. K. (2010): Comparative study of benthic macroinvertebrates in the Eastern and Western parts of Lagos Lagoon, Nigeria. Environmental Research Journal, 4, 2, 182-186.

Nkwoji, J. A., Yakub, A., Ajani, G. F., Balogun, K. J., Renner, K. O., Igbo, J. K., Ariyo, A. A., Bello, B.O. (2010): Seasonal variations in water chemistry and benthic macro invertebrates of a South Western Lagoon, Lagos, Nigeria. Journal of Atmospheric Sciences, 6, 3, 85-92.

Nwankwo, D. I. (1996): Phytoplankton diversity and succession in Lagos Lagoon, Nigeria. Archives Fur Hydrobiologie, 135, 4, 529-542.

Nwankwo, D. I., Chukwu, L. O., Abiola, O. (2014): Effect of waste heat from Egbin thermal plant on the plankton and macrobenthos of Lagos Lagoon. Journal of Environment and Ecology, 5, 1, 62-78.

Ogunwenmo, C. A., Kusemiju, K. (2004): Annelids of West Africa estuarine systems. Journal of Environmental Biology, 25, 6, 227-237.

Olaniyan, C. I. O. (1969): The seasonal variation in the hydrobiology and total plankton of the lagoons of South West Nigeria. Nigerian Journal of Science, 3,101119.

Olaniyan, C. I. O. (1975): An Introduction to West African Ecology. Hemernann Education Books Ltd. London. 170pp.

Omogoriola, H. O., Williams, A. B., Ukaonu, S. C., Adegbile, O. M., Olakolu, F. C., Mbawuike, B.C., Akinnigbagbe, A.E., Ajulo, A.A. (2012): Survey, biodiversity and impacts of economic activities on mangroves ecosystem in eastern part of Lagos Lagoon, Nigeria. Nature Science, 10, 10, 30-34.

Onyema, I. C., Okpara, C., Ogbebor, C. I., Otudeko, O., Nwankwo, D. I. (2007): Comparative studies of the water chemistry characteristics and temporal plankton variations at two polluted sites along the Lagos Lagoon, Nigeria. Ecology, Environment and Conservation, 13, 1, 1-12.

Onyema, I. C. (2013): The water quality conditions and phytoplankton of two mangrove creeks and an adjoining lagoon. Research Journal of Pharmaceutical, Biological and Chemical Sciences, 4, 3, 627-638.

Ovie, S. I., Adepoju, F., Ajayi, O. (2009): Limnological Stock Assessment, Productivity and Potential Fish Yield of Dadin Kowa and Kiri reservoirs.In: Ovie, S.I. and Ajayi, O. Preliminary Studies on the Limnological Stock Assessment, Productivity and Potential Fish Yield of Ojirami Reservoir, Edo State, Nigeria. Trop. Freshw. Biol., 18, 1, 1-8

Patrick, R., Reimer, C. W. (1975): The diatoms of the United States exclusive of Alaska and Hawaii. Monogr. Academy National Science, Philadelphia, 2, 1, 213.

Pennak, E. A. (1978): Freshwater invertebrates of the United States. 2nd Edition, John Wiley and Sons, New York. 803 pp. 
Phillips, O. A., Falana, A. O., Olayinola, M. A. (2012): Assessment of environmental impact on benthic foraminifera distribution in Lagos Lagoon, Nigeria. Journal of Mining and Geology, 48, 1, 68-78.

Popoola, K. O. K., Otalekor, A. (2011): Analyasis of aquatic insects community of Awba Resevoir and its physic -chemical properties. Research Journal of Environmental and earth Science, 3, 422-428.

Popoola, S. O., Udochu, U., Adekunbi, F. O., Nwoko, C. J., Fashade, A. O. (2015): Spatial variations in the physicochemical parameters of some selected locations in Lagos Lagoon, Southwestern Nigeria. Journal of Science 5, 12, 1354-1359.

Uwadiae, R. E. (2009): Response of benthic macroinvertebrate community to salinity gradient in a sandwiched coastal lagoon. Reports and Opinion, 1, 4, 45-55.
Wen Z., Zhi-Hui, H. (1999): Biological and ecological features of inland saline waters in North Hebei, China. International J Salt Lake Res. 8, 267-285.

Whitford, L. A., Schumacher, G. J. (1973): A Manual of Fresh Water Algae. Raleigh, North Carolina. 541 pp.

Wimpenny, R. S. (1966): The plankton of the sea. Faber and Faber Limited, London. $455 \mathrm{pp}$.

Yakub, A. S., Balogun, K. J., Ajani, G. E., Renner, K. O., Bello, B. O., Nkwoji, J. A., Igbo, J. K. (2012): Seasonal variations in the composition and distribution of planktonic fauna in the eastern Lagos Lagoon, Nigeria. Journal of Applied Sciences and Environmental Management, 16, 1, 45-53 